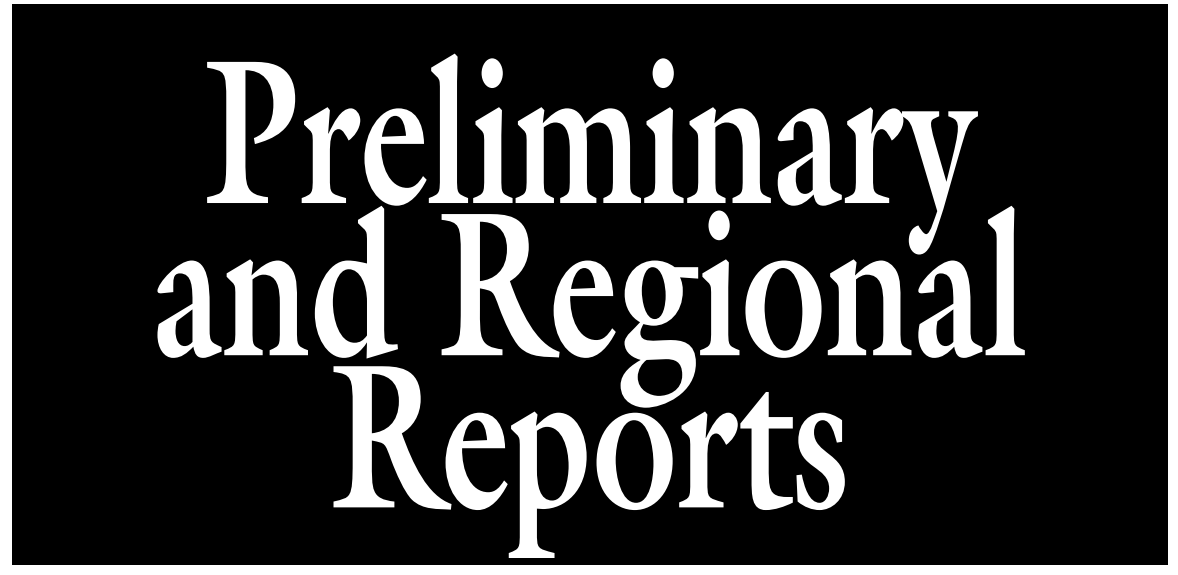

\title{
Soil Fumigants to Replace Methyl Bromide for Weed Control in Ornamentals
}

\author{
Robert E. Uhlig ${ }^{1,4}$, George Bird ${ }^{2}$, Robert J. Richardson ${ }^{3}$, and \\ Bernard H. Zandstra ${ }^{1}$
}

ADDITIONAL INDEX wORDS. 1,3-dichloropropene, dazomet, iodomethane, metham sodium, chloropicrin

Summary. A field study was conducted to evaluate fumigant alternatives for methyl bromide (MB). Iodomethane (IM), chloropicrin (CP), 1,3-dichloropropene (1,3-D), metham sodium (MS), and MB in various combinations were applied to a sandy soil field site in Sept. 2002. Some treatments were tarped. Plant injury, plant growth, fresh weight, and dry weight were evaluated for seven ornamental species: cushion spurge (Euphorbia polychroma), globe thistle (Echinops bannaticus 'Blue Globe'), common lavender (Lavandula angustifolia 'Hidcote Blue'), hosta (Hosta 'Twilight PP14040'), silvermound artemisia (Artemisia schmidtiana 'Silver Mound'), shasta daisy (Leucanthemum $\times$ superbum 'Snow Lady'), and thread leaf coreopsis (Coreopsis verticillata 'Moonbeam'). Weed control was evaluated in Apr. 2003, July 2003, and May 2004. All treatments gave almost complete control of all annual weeds, except for IM 50\% + CP 50\% (200 lb/acre, tarped) and MS (75 gal/acre, 1:4 water, not tarped), which did not give adequate control of common chickweed (Stellaria media), mouseear cress (Avabidopsis thaliana), common lambsquarters (Chenopodium album), or common purslane (Portulaca oleracea). None of the treatments caused visual injury to any crop species. Treatments did not affect plant size in Nov. 2003. However, some treatments resulted in larger thread leaf coreopsis and silvermound artemisia plants in May 2004. There was no difference in dry weight at harvest between treatments for all species.

$\mathrm{F}$ umigants are used to control soil-borne pests to obtain larger yields of high-quality horticultural products (Messenger and Braun, 2000). Methyl bromide has been the most widely used fumigant, with $68,424 \mathrm{t}$ used worldwide in 1996.

${ }^{1}$ Department of Horticulture, Michigan State University, Plant and Soil Sciences Building, East Lansing, Michigan 48824-1325.

${ }^{2}$ Department of Entomology, Michigan State University, Natural Science Building, East Lansing, Michigan 48824-1115.

${ }^{3}$ Crop Science Department, North Carolina State University, Williams Hall, Box 7620, Raleigh, North Carolina 27695

${ }^{4}$ Corresponding author. E-mail: uhlig@msu.edu
The United States uses almost half of world consumption of methyl bromide $(\mathrm{MB})$, and $70 \%$ of that is used for soil fumigation (Ware and Whitacre, 2004). Atmospheric MB originates from oceanic emissions and anthro- pogenic sources, such as biomass burning, agricultural applications, leaded gasoline combustion, and structural fumigation. The relative contributions of anthropogenic and natural emissions to total atmospheric $\mathrm{MB}$ are not well known (Butler and Rodriguez, 1996). However, it was estimated that anthropogenic sources account for $20 \%$ to $50 \%$ (Singh and Kanakidou, 1993).

Methyl bromide research has been conducted extensively in highvalue crops such as tobacco (Nicotiana tabacum), tomato (Lycopersicon esculentum), pepper (Capsicum annum), cucumber (Cucumis satious), and strawberry (Fragaria Xananassa) (Csinos et al., 2000; Fennimore et al., 2003; Gilreath et al., 2004). However, there has been limited research reported for $\mathrm{MB}$ alternatives in ornamentals (Carpenter et al., 2000; Schneider et al., 2003).

The manufacture and importation of $\mathrm{MB}$ was essentially phased out in developed countries for general agricultural uses in 2005, and developing countries have agreed to eliminate most chlorofluorocarbons (CFC) by Jan. 2010 (United Nations Development Programme, 2006). The MB phaseout will affect agricultural production adversely, especially where alternative fumigants are not available. For example, the ornamental and nursery industries may lose $\$ 129$ million in California and \$14 million in North Carolina, due to differences in yield and control costs between the alternatives and $\mathrm{MB}$ (Carpenter et al., 2000). Loss of MB will affect cut-flower and ornamental crop production adversely more than other industries because breeding programs focus primarily on plant aesthetic qualities and not on disease tolerance, often leaving crops susceptible to diseases (Sances, 2005).

Metham sodium, chloropicrin, 1,3-dichloropropene, and iodomethane are potential substitutes for

\begin{tabular}{llll}
\hline $\begin{array}{l}\text { Units } \\
\text { To convert U.S. to SI, } \\
\text { multiply by }\end{array}$ & U.S. unit & SI unit & $\begin{array}{l}\text { To convert SI to U.S., } \\
\text { multiply by }\end{array}$ \\
\hline 0.3048 & $\mathrm{ft}$ & $\mathrm{m}$ & 3.2808 \\
9.3540 & gal $/ \mathrm{acre}$ & $\mathrm{L} \cdot \mathrm{ha}^{-1}$ & 0.1069 \\
2.54 & inch $(\mathrm{es})$ & $\mathrm{cm}$ & 0.3937 \\
0.4536 & $\mathrm{lb}$ & $\mathrm{kg}$ & 2.2046 \\
1.1209 & $\mathrm{lb} / \mathrm{acre}$ & $\mathrm{kg} \cdot \mathrm{ha}^{-1}$ & 0.8922 \\
6.8948 & $\mathrm{psi}$ & $\mathrm{kPa}$ & 0.1450 \\
$\left({ }^{\circ} \mathrm{F}-32\right) \div 1.8$ & ${ }^{\circ} \mathrm{F}$ & ${ }^{\circ} \mathrm{C}$ & $\left(1.8 \times{ }^{\circ} \mathrm{C}\right)+32$
\end{tabular}


Table 1. Weed control ratings 7 and 10 months after fumigation on 12 Sept. 2002, on a loamy sand soil, Hudsonville, Mich.; fumigants were injected $6-8$ inches $(15.2-20.3 \mathrm{~cm})$ below the surface at a pressure of $80-120 \mathrm{psi}(551.6-827.4 \mathrm{kPa})$.

\begin{tabular}{|c|c|c|c|c|c|c|c|c|c|c|}
\hline \multirow[b]{3}{*}{ Treatment $^{\mathrm{y}}$} & \multirow[b]{3}{*}{ Tarp } & \multirow[b]{3}{*}{ Rate $^{\mathrm{x}}$} & \multicolumn{8}{|c|}{ Control rating $^{z}$} \\
\hline & & & \multicolumn{3}{|c|}{24 Apr. 2003} & \multicolumn{5}{|c|}{9 July 2003} \\
\hline & & & MECR $^{w}$ & COGR & COCW & RRPW & COLQ & COPU & COGR & YEFT \\
\hline Non-treated (tarped) & Yes & - & $7.0 \mathrm{~b}$ & $8.1 \mathrm{a}$ & $6.3 \mathrm{~b}$ & $1.0 \mathrm{c}$ & $1.0 \mathrm{~d}$ & $1.0 \mathrm{c}$ & $1.0 \mathrm{~b}$ & $1.0 \mathrm{c}$ \\
\hline $\mathrm{IM}(50 \%)+50 \% \mathrm{CP}$ & Yes & $300 \mathrm{lb} /$ acre & $9.8 \mathrm{a}$ & $10 \mathrm{a}$ & $9.8 \mathrm{a}$ & $10 \mathrm{a}$ & $10 \mathrm{a}$ & $9.2 \mathrm{a}$ & $9.8 \mathrm{a}$ & $10 \mathrm{a}$ \\
\hline $\mathrm{IM}(50 \%)+50 \% \mathrm{CP}$ & Yes & $200 \mathrm{lb} /$ acre & $1.8 \mathrm{c}$ & $6.0 \mathrm{~b}$ & $2.1 \mathrm{~d}$ & $8.8 \mathrm{a}$ & $8.3 \mathrm{bc}$ & $5.7 \mathrm{~b}$ & $8.3 \mathrm{a}$ & $9.5 \mathrm{a}$ \\
\hline $\mathrm{IM}(98 \%)+2 \% \mathrm{CP}$ & Yes & $150 \mathrm{lb} / \mathrm{acre}$ & $9.5 \mathrm{a}$ & $10 \mathrm{a}$ & $9.8 \mathrm{a}$ & $10 \mathrm{a}$ & $10 \mathrm{a}$ & $9.3 \mathrm{a}$ & $9.8 \mathrm{a}$ & $10 \mathrm{a}$ \\
\hline MS & No & $75 \mathrm{gal} /$ acre ( $1: 4$ water $)$ & $3.0 \mathrm{c}$ & $9.7 \mathrm{a}$ & $5.0 \mathrm{c}$ & $9.5 \mathrm{a}$ & $7.5 \mathrm{c}$ & $5.0 \mathrm{~b}$ & $9.5 \mathrm{a}$ & $8.5 \mathrm{a}$ \\
\hline MS & Yes & $75 \mathrm{gal} /$ acre $(1: 2$ water $)$ & $9.0 \mathrm{a}$ & $10 \mathrm{a}$ & $9.3 \mathrm{a}$ & $9.7 \mathrm{a}$ & $10 \mathrm{a}$ & $9.0 \mathrm{a}$ & $9.7 \mathrm{a}$ & $10 \mathrm{a}$ \\
\hline MS & Yes & $75 \mathrm{gal} /$ acre ( $1: 4$ water $)$ & $9.5 \mathrm{a}$ & $10 \mathrm{a}$ & $9.7 \mathrm{a}$ & $10 \mathrm{a}$ & $10 \mathrm{a}$ & $9.2 \mathrm{a}$ & $10 \mathrm{a}$ & $10 \mathrm{a}$ \\
\hline $1,3-\mathrm{D}(97.5 \%)^{\mathrm{t}}$ & Yes & $35 \mathrm{gal} / \mathrm{acre}$ & $10 \mathrm{a}$ & $10 \mathrm{a}$ & $10 \mathrm{a}$ & $10 \mathrm{a}$ & $10 \mathrm{a}$ & $9.3 \mathrm{a}$ & $9.7 \mathrm{a}$ & $10 \mathrm{a}$ \\
\hline
\end{tabular}

${ }^{\mathrm{z}}$ Control was evaluated on a scale from 1 to 10 , where $1=$ no weed control and $10=$ total weed control.

${ }^{y} \mathrm{IM}=$ iodomethane; $\mathrm{CP}=$ chloropicrin; $1,3-\mathrm{D}=1,3$-dichloropropene; $\mathrm{MB}=$ methyl bromide; $\mathrm{MS}=$ metham sodium

${ }^{x} 1 \mathrm{lb} /$ acre $=1.1209 \mathrm{~kg} \cdot \mathrm{ha}^{-1}, \mathrm{l} \mathrm{gal} /$ acre $=9.3540 \mathrm{~L} \cdot \mathrm{ha}^{-1}$.

${ }^{w}$ MECR $=$ mouseear cress $(A$. thaliana $), \mathrm{COGR}=$ common groundsel $($ Senecio vulgaris $), \mathrm{COCW}=\operatorname{common}$ chickweed $(S$. media $), \mathrm{RRPW}=\operatorname{redroot}$ pigweed $($ Amarantus retroflexus), COLQ = common lambsquarters (Chenopodium album), COPU = common purslane $($ Portulaca oleracea $)$, YEFT $=$ yellow foxtail $($ Setaria glauca $)$.

"Within columns, means followed by same letter are not different at $P \leq 0.05$.

"Telone C-35 (Dow Agrosciences LLC).

tTelone II (Dow Agrosciences LLC).

Table 2. Weed control ratings on 7 May 2004, 20 months after fumigation on 12 Sept. 2002, on a loamy sand soil, Hudsonville, Mich.; fumigants were injected 6-8 inches $(15.2-20.3 \mathrm{~cm})$ below the surface at a pressure of $80-120 \mathrm{psi}(551.6-827.4 \mathrm{kPa})$.

\begin{tabular}{|c|c|c|c|c|c|c|c|}
\hline \multirow[b]{2}{*}{ Treatment $^{\mathrm{y}}$} & \multirow[b]{2}{*}{ Tarp } & \multirow[b]{2}{*}{ Rate $^{\mathrm{x}}$} & \multicolumn{5}{|c|}{ Control rating $^{\mathrm{z}}$} \\
\hline & & & MECR $^{\mathbf{w}}$ & PRLE & COMA & COCW & RECL \\
\hline Non-treated & No & - & $1.0 \mathrm{e}^{\mathrm{v}}$ & $1.0 \mathrm{c}$ & $1.0 \mathrm{c}$ & $1.0 \mathrm{c}$ & $1.0 \mathrm{c}$ \\
\hline $\mathrm{IM}(50 \%)+50 \% \mathrm{CP}$ & Yes & $300 \mathrm{lb} /$ acre & $7.5 \mathrm{ab}$ & $6.8 \mathrm{abc}$ & $10 \mathrm{a}$ & $8.5 \mathrm{a}$ & $9.5 \mathrm{ab}$ \\
\hline $\mathrm{IM}(50 \%)+50 \% \mathrm{CP}$ & Yes & $200 \mathrm{lb} /$ acre & $4.0 \mathrm{~cd}$ & $8.3 \mathrm{ab}$ & $9.0 \mathrm{a}$ & $2.6 \mathrm{c}$ & $10 \mathrm{a}$ \\
\hline $1,3-\mathrm{D}(64 \%)+35 \% \mathrm{CP}$ & Yes & $35 \mathrm{gal} / \mathrm{acre}$ & $8.7 \mathrm{a}$ & $6.7 \mathrm{abc}$ & $9.2 \mathrm{a}$ & $8.5 \mathrm{a}$ & $8.3 \mathrm{ab}$ \\
\hline MS & No & $75 \mathrm{gal} /$ acre $(1: 4$ water $)$ & $5.8 \mathrm{bc}$ & $7.0 \mathrm{ab}$ & $9.8 \mathrm{a}$ & $4.5 \mathrm{~b}$ & $9.7 \mathrm{a}$ \\
\hline MS & Yes & $75 \mathrm{gal} /$ acre $(1: 2$ water $)$ & $8.3 \mathrm{a}$ & $7.3 \mathrm{ab}$ & $9.2 \mathrm{a}$ & $8.3 \mathrm{a}$ & $9.5 \mathrm{ab}$ \\
\hline MS & Yes & $75 \mathrm{gal} /$ acre (1:4 water) & $8.8 \mathrm{a}$ & $7.3 \mathrm{ab}$ & $10 \mathrm{a}$ & $8.5 \mathrm{a}$ & $9.0 \mathrm{ab}$ \\
\hline $1,3-\mathrm{D}(97.5 \%)$ & Yes & $35 \mathrm{gal} /$ acre & $7.6 \mathrm{ab}$ & $9.0 \mathrm{a}$ & $8.6 \mathrm{a}$ & $7.8 \mathrm{a}$ & $9.8 \mathrm{a}$ \\
\hline $1,3-\mathrm{D}(97.5 \%)+\mathrm{MS}$ & Yes & $\begin{array}{l}35 \mathrm{gal} / \mathrm{acre}+75 \mathrm{gal} / \mathrm{acre} \\
\text { (1:4 water) }\end{array}$ & $8.7 \mathrm{a}$ & $5.8 \mathrm{bc}$ & $8.0 \mathrm{a}$ & $9.0 \mathrm{a}$ & $8.7 \mathrm{ab}$ \\
\hline
\end{tabular}

${ }^{2}$ Control was evaluated on a scale 1 to 10 , where $1=$ no weed control and $10=$ total weed control.

${ }^{y} \mathrm{IM}=$ iodomethane; $\mathrm{CP}=$ chloropicrin; $1,3-\mathrm{D}=1,3$-dichloropropene; $\mathrm{MB}=$ methyl bromide; $\mathrm{MS}=$ metham sodium

${ }^{x} \mathrm{l} \mathrm{lb} /$ acre $=1.1209 \mathrm{~kg} \cdot \mathrm{ha}^{-1}, \mathrm{l} \mathrm{gal} / \mathrm{acre}=9.3540 \mathrm{~L} \cdot \mathrm{ha}^{-1}$.

${ }^{\mathrm{w}} \mathrm{MECR}=$ mouseear cress $($ A. thaliana $), \mathrm{PRLE}=$ prickly lettuce $($ L. serriola $), \mathrm{COMA}=$ common mallow $($ Malva neglecta $), \mathrm{COCW}=$ common chickweed $(S$. media $), \mathrm{RECL}=$ red clover (Trifolium pratense)

"Within columns, means followed by same letter are not different at $P \leq 0.05$.

$\mathrm{MB}$ in ornamental production. The objective of this study was to evaluate crop safety and weed control with pre-transplant applications of these fumigants on seven ornamental species.

\section{Materials and methods}

The experiment was conducted at a commercial nursery in Hudsonville, Mich., on a Granby loamy sand (sandy, mixed, noncalcareous, mesic, typic Haplaquolls) with
$81 \%$ sand, $8 \%$ silt, $11 \%$ clay, $2.5 \%$ organic matter, $\mathrm{pH}$ of 6.2 , and cation exchange capacity of $9.3 \mathrm{meq} / 100 \mathrm{~g}$.

The treatments were applied by a commercial applicator on 12 Sept. 2002. The fumigants were injected 
Table 3. Effect of dazomet applied on 12 Sept. 2002 before transplanting on seven ornamental plant species; ornamentals were evaluated for crop injury (20 Aug. 2003), size (19 May 2004), and dry weight (Sept.-Oct. 2004).

\begin{tabular}{|c|c|c|c|c|c|c|c|}
\hline Treatment $^{\mathrm{z}}$ & $\begin{array}{c}\text { Silvermound } \\
\text { artemisia }\end{array}$ & $\begin{array}{c}\text { Thread leaf } \\
\text { coreopsis }\end{array}$ & Globe thistle & Cushion spurge & Hosta & Common lavender & Shasta daisy \\
\hline & \multicolumn{7}{|c|}{ Injury rating ${ }^{y}$} \\
\hline Untreated & $1.0 \mathrm{a}^{\mathrm{x}}$ & $1.0 \mathrm{a}$ & $1.0 \mathrm{a}$ & $1.0 \mathrm{~b}$ & $1.0 \mathrm{a}$ & $1.0 \mathrm{a}$ & $1.0 \mathrm{a}$ \\
\hline \multirow[t]{2}{*}{ Dazomet } & $1.0 \mathrm{a}$ & $1.3 \mathrm{a}$ & $1.6 \mathrm{a}$ & $2.6 \mathrm{a}$ & $1.0 \mathrm{a}$ & $1.6 \mathrm{a}$ & $1.0 \mathrm{a}$ \\
\hline & \multicolumn{7}{|c|}{ Size index $[($ height + width $) / 2](\mathrm{cm})^{\mathrm{w}}$} \\
\hline Untreated & $21.0 \mathrm{a}$ & $37.9 \mathrm{a}$ & $43.4 \mathrm{a}$ & $46.1 \mathrm{a}$ & $14.6 \mathrm{a}$ & $32.9 \mathrm{a}$ & $25.0 \mathrm{a}$ \\
\hline Untreated & $2.27 \mathrm{a}$ & $2.56 \mathrm{a}$ & $1.19 \mathrm{a}$ & $1.29 \mathrm{a}$ & $0.11 \mathrm{a}$ & $2.25 \mathrm{a}$ & $1.02 \mathrm{a}$ \\
\hline Dazomet & $2.30 \mathrm{a}$ & $2.03 \mathrm{a}$ & $0.73 \mathrm{a}$ & $0.53 \mathrm{a}$ & $0.14 \mathrm{a}$ & $1.28 \mathrm{~b}$ & $0.91 \mathrm{a}$ \\
\hline
\end{tabular}

${ }^{2}$ Dazomet $99 \%$ granular was applied at $350 \mathrm{lb} /$ acre evenly over the plot surface and incorporated immediately after application with a rototiller. The plots were not tarped. 'Injury was rated visually on a 1 to 10 scale, where $1=$ no injury and $10=$ dead plant.

'Within columns, means followed by same letter are not different at $P \leq 0.05$.

" $1 \mathrm{~cm}=0.3937$ inch, $1 \mathrm{~kg}=2.2046 \mathrm{lb}$.

v Dry weight means are total of five plants for each plot.

6-8 inches below the surface with a nitrogen-pressurized fumigation machine at a pressure of $80-120 \mathrm{psi}$, mounted on a tractor with 11 chisels per bed spaced 12.5 inches apart. Treatments were IM 50\% + CP $50 \%$ (tarped, $300 \mathrm{lb} /$ acre); IM 50\% + CP $50 \%$ (tarped, $200 \mathrm{lb} /$ acre); $1,3-\mathrm{D}$ 64\% + CP 35\% [Telone C-35 (Dow Agrosciences LLC, Indianapolis), tarped, $35 \mathrm{gal} / \mathrm{acre}] ; \mathrm{MB} 98 \%+\mathrm{CP}$ $2 \%$ (tarped, $350 \mathrm{lb} /$ acre); IM 98\% + CP 2\% (tarped, $150 \mathrm{lb} /$ acre); MS (not tarped, $75 \mathrm{gal} /$ acre, $1: 4$ water); MS (tarped, $75 \mathrm{gal} /$ acre, l:2 water); MS (tarped, $75 \mathrm{gal} /$ acre, $1: 4$ water); 1,3-D 97.5\% [Telone II (Dow Agrosciences LLC), tarped, $35 \mathrm{gal} /$ acre]; 1,3-D 97.5\% + MS (tarped, $35 \mathrm{gal} /$ acre $+75 \mathrm{gal} /$ acre, $1: 4$ water $) ; \mathrm{MB}$ $67 \%+$ CP 33\% (tarped, $350 \mathrm{lb} /$ acre); and 1,3-D 64\% + CP 35\% and MS (tarped, $35 \mathrm{gal} / \mathrm{acre}+75 \mathrm{gal} / \mathrm{acre}$, $1: 4$ water). Plot size was $13 \times 100 \mathrm{ft}$. Plots were tarped with clear plastic mulch immediately after application, except the untreated control and MS (75 gal/acre, 1:4 water), which remained uncovered. Soil temperature at application was $72^{\circ} \mathrm{F}$ at 5 inches.

Seven ornamental species (cushion spurge, globe thistle, common lavender, hosta, silvermound artemisia, Shasta daisy, and thread leaf coreopsis) were transplanted in June 2003 (9 months after treatment). Plants were planted in 4 rows $2 \mathrm{ft}$ apart at the center of the fumigated area. The number of plants planted in each plot varied among species: 15-20 common lavender plants, six to eight plants of cushion spurge, globe thistle, and hosta, and a complete row (25-30 plants) of Shasta daisy and thread leaf coreopsis.
Plant injury was rated for each species on 23 July and 20 Aug. 2003 using a scale of $l$ to 10 , with $l=$ no injury and $10=$ dead plant. Weed control was rated for the whole plot on 24 Apr. and 9 July 2003 and 7 May 2004. Plant size was measured on 14 Nov. 2003 and 19 May 2004. Measurements were taken in 10 plants for all species except for cushion spurge and globe thistle, for which six to eight plants were measured, because of the smaller number of total plants in the plots. Plant size index was used to evaluate plant growth and was determined by adding the highest point and the widest point of the plant and dividing by 2 (Briggs and Whitwell, 2002).

Five plants of each species were randomly selected, dug, and placed in plastic bags in Sept.-Oct. 2004. All plants of a species were harvested the same day. The plants were kept in a cold room at $41{ }^{\circ} \mathrm{F}$ until they were weighed. Plants were separated into foliage and roots, and each plant part was weighed separately. The plants were then dried at $105^{\circ} \mathrm{F}$ for $10 \mathrm{~d}$ and weighed again.

A randomized complete-block design was used for data analysis. Each species was analyzed separately. The experiment had six replications in the field. All data were subjected to analysis of variance and Fisher's protected least significant difference $(P=$ $0.05)$ was used for mean separation. Data were analyzed using the general linear model procedure (SAS Institute, Cary, N.C.).

Dazomet was included in three of the six replications and data were analyzed separately in a single degree contrast with the untarped control. Dazomet 99\% granular was applied at $350 \mathrm{lb} /$ acre evenly over the plot surface and incorporated immediately after application with a rototiller. The plots were not tarped.

\section{Results and discussion}

All the treatments controlled $80 \%$ to $100 \%$ of annual weeds, except IM 50\% + CP 50\% (200 lb/acre, tarped) and MS (1:4 water, $75 \mathrm{gal} /$ acre, not tarped), which had poor control of common chickweed and mouseear cress in Apr. 2003 and May 2004 (Tables 1 and 2), and common lambsquarters and common purslane in July 2003 (Table 1). However, IM $50 \%+$ CP $50 \%$ (300 lb/acre, tarped) had almost $100 \%$ control of these weeds at 7 and 10 months after fumigation, suggesting that $200 \mathrm{lb} /$ acre was too low a rate for total weed control and that the effective rate must be between 200 and $300 \mathrm{lb} /$ acre. These results are similar to those of Shrestha et al. (2005), who observed similar weed control with $\mathrm{MB}+\mathrm{CP}$ $(400 \mathrm{lb} / \mathrm{acre})$ and IM + CP (400 lb/ acre). Schneider et al. (2005) also reported that IM $67 \%+$ CP $33 \%$ (300 lb/acre, shanked, tarped) gave weed control comparable to $\mathrm{MB}$ at $600 \mathrm{lb} /$ acre.

MS (75 gal/acre, 1:4 water, not tarped) did not control weeds as well as in the same tarped treatment, indicating that tarping after fumigation was an important factor in controlling weeds. This result agrees with the findings of Csinos et al. (1997), who found that pest control in tobacco and pepper were better with MS 
(51 gal/acre) plus 1,3-D 83\% + CP $17 \%$ (13 gal/acre) covered immediately with polyethylene compared with a similar treatment sealed mechanically but not tarped, and of Unruh et al. (2002), who found poorer weed control with MS + CP (80 gal/acre + $15 \mathrm{gal} / \mathrm{acre}$, not tarped) compared with $\mathrm{MB}$ at 5 weeks after fumigation.

There was no crop injury from any of the treatments in July and Aug. 2003. There were no differences in plant size between treatments in Nov. 2003. However, in May 2004, larger silvermound artemisia and thread leaf coreopsis plants were observed in plots treated with 1,3-D 64\% + CP $35 \%$ (tarped, $35 \mathrm{gal} /$ acre), IM 98\% + CP 2\% (tarped, $150 \mathrm{lb} /$ acre), MS (tarped, $75 \mathrm{gal} /$ acre, 1:4 water), 1,3-D 97.5\% (tarped, $35 \mathrm{gal} /$ acre), 1,3-D 97.5\% + MS (tarped, $35 \mathrm{gal} /$ acre, $75 \mathrm{gal} /$ acre, $1: 4$ water), and $\mathrm{MB}$ $67 \%+$ CP 33\% (tarped, $350 \mathrm{lb} /$ acre) . In addition, $\mathrm{MB} 98 \%+\mathrm{CP} 2 \%$ (tarped, $350 \mathrm{lb} /$ acre) and 1,3-D $64 \%+$ CP $35 \%$ and MS (tarped, 35 gal/acre + $75 \mathrm{gal} / \mathrm{acre}, \mathrm{l}: 4$ water) resulted in larger plants in silvermound artemisia, and MS (tarped, $75 \mathrm{gal} / \mathrm{acre}, 1: 2$ water) resulted in larger plants in thread leaf coreopsis. The increase in size may be caused by a reduction in weed competition with the crop. In a similar experiment, Gerik (2005) did not find differences in plant height of stock (Matthiola spp.), snapdragon (Antirrbinum majus), and dutch iris (Iris xiphium) grown in soil previously drip fumigated with MB 50\% + CP 50\% (400 lb/acre), IM 50\% + CP 50\% (400 lb/acre), and 1,3-D 61\% + CP 33\% (395 lb/acre).

No differences between treatments in total fresh weight, root fresh weight, total dry weight, root dry weight, and foliage dry weight were observed. The 1,3-D 64\% + CP 35\% (35 gal/acre, tarped) and IM 98\% + CP 2\% (150 lb/acre, tarped) treatments reduced foliage fresh weight of cushion spurge $(P=0.045)$, and IM $50 \%+$ CP $50 \%$ (300 lb/acre, tarped) and MS (75 gal/acre, l:4 water, tarped) reduced foliage fresh weight of common lavender $(P=0.048)$.

Dazomet gave good control of all weeds except for prickly lettuce (Lactuca serriola) in May 2004. It caused injury (2.6 out of 10) and reduced plant size in cushion spurge. Dazomet reduced total dry weight in common lavender (Table 3 ).

In conclusion, most fumigants tested provided good weed control up to 20 months after application. IM $50 \%+$ CP 50\% (200 lb/acre, tarped) and MS (75 gal/acre, 1:4 water, not tarped) had the poorest control of most summer annual weeds. In the first case, lower rate, and in the second case, no tarp, could be the factors that contributed to the inadequate weed control. Fumigants did not injure the ornamental crops evaluated in this experiment, and some of the treatments increased plant size in two species.

All of the fumigants tested appear to have potential to replace MB in ornamental production. They were safe to the ornamental species studied, and they provided effective weed control.

\section{Literature cited}

Briggs, J. and T. Whitwell. 2002. Effect of prodiamine formulation on injury to ornamentals. Southern Nursery Assn. Res. Conf. 47:384-388.

Butler, J.H. and J.M. Rodriguez. 1996. Methyl bromide in the atmosphere, p. 28-83. In: C.H. Bell, N. Price, and B. Chakrabarti (eds.). The methyl bromide issue, Vol. 1. Wiley, Chichester, England.

Carpenter, J., G. Leonard, and L. Lori. 2000. The economic impact of the scheduled U.S. phaseout of methyl bromide. Natl. Ctr. for Food and Agr. Policy, Washington, D.C.

Csinos, A.S., W.C. Johnson, A.W. Johnson, D.R. Sumner, R.M. McPherson, and R.D. Gitaitis. 1997. Alternative fumigants for methyl bromide in tobacco and pepper transplant production. Crop Prot. $16: 585-594$.

Csinos, A.S., D.R. Sumner, W.C. Johnson, A.W. Johnson, R.M. McPherson, and C.C. Dowler. 2000. Methyl bromide alternatives in tobacco, tomato and pepper transplant production. Crop Prot. 19:39-49.

Fennimore, S.A., M.J. Haar, and H.A. Ajwa. 2003. Weed control in strawberry provided by shank and drip-applied methyl bromide alternative fumigants. HortScience 38:55-61.
Gerik, J.S. 2005. Drip applied alternatives for floriculture production. 27 Oct. 2006. <http://www.mbao.org/2005/ 05Proceedings/105GerikJ Drip Applied Alternatives for Floriculture Production.pdf>.

Gilreath, J.P., J.W. Noling, and B.M. Santos. 2004. Methyl bromide alternatives for bell pepper (Capsicum annum) and cucumber (Cucumis sativus) rotations. Crop Prot. 23:347-351.

Messenger, B. and A. Braun. 2000. Alternatives to methyl bromide for the control of soil-borne diseases and pests in California. California Dept. of Pesticide Regulat., Fumigant Resource Ctr., Sacramento.

Sances, F.V. 2005. Ten years of methyl bromide alternatives research and development: Lessons learned. 27 Oct. 2006. $<$ ht p://www.mbao.org/2005/ 05Proceedings/018SancesF mbao 2005 abstract 8-31-05.pdf>.

Schneider, S., E.N. Rosskopf, J.G. Leesch, D.O. Chellemi, C.T. Bull, and M. Mazzola. 2003. United States Department of Agriculture-Agricultural Research Service research on alternatives to methyl bromide: Pre-plant and postharvest. Pest Mgt. Sci. 59:814-826.

Schneider, S., T. Trout, J. Gerik, A. Shrestha, and R. Rodriguez-Kabana. 2005. Methyl bromide alternatives for perennial crop field nurseries. 27 Oct. 2006. <http://www.mbao.org/2005/ 05Proceedings/041SchneiderS Nursery paper MBAO 2005.pdf $>$.

Shrestha, A., G.T. Browne, B.D. Lampinen, S. Schneider, L. Simon, and T. Trout. 2005. Weed populations in nurseries as affected by methyl bromide and alternative fumigants. 27 Oct. 2006. <http:// www.mbao.org/2005/05Proceedings/ 046ShresthaA abstract_MB2005.pdf>.

Singh, H.B. and M. Kanakidou. 1993. An investigation of the atmospheric sources and sinks of methyl bromide. Geophys. Res. Lett. 20:133-136.

United Nations Development Programme. 2006. The Vienna Convention and the Montreal Protocol. 31 Oct. 2006. <http://www.undp.org/montrealprotocol/ montreal_newl.htm>.

Unruh, J.B., B.J. Brecke, J.A. Dusky, and J.S. Godbehere. 2002. Fumigant alternatives for methyl bromide prior to turfgrass establishment. Weed Technol. 16:379-387.

Ware, G.W. and D.M. Whitacre. 2004. The pesticide book. 6th ed. MeisterPro Info. Resources, Willoughby, Ohio. 